\title{
MOLTING OF BROILER BREEDERS CONDITIONS FOR ECONOMIC JUSTIFICATION IN CONTINUED PRODUCTION
}

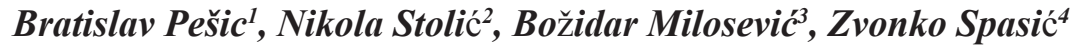

\begin{abstract}
Summary
The method of artificial interruption of the production process by hens, broiler breeders, today known as the molting, it is often used in recent years as one of possible reasonable steps in making decisions on feasibility of continuing exploitation of broiler breeder safter the regular production process. The aim of this study was to test the economic profitability molting hens-broiler, during one exploitation period. It included the throat of hybrid heavy line COBB500. The animals in the house were exposed to the same microclimate conditions, with identical positions in relation to light, ventilation, water, food and fertilization system. The analysis of food consumption per produced egg can be notice that parents' hens during the process of molting consume more food by $43 \%$ compared to the hens fed the normal cycle of production. Achieved income was $2.54 \%$ higher after billing code for molting chickens instead of the regular production cycle. Economic indicators egg production after molting demonstrate justification of these biological and technological operations, considering that the net income per hen housed is the same income in the normal production process.
\end{abstract}

Key words: molting, broiler breeders, capacity, chickens, economy.

JEL: $Q 10, Q 11, Q 13$

\section{Introduction}

Intensification of production processes in poultry, improvement of the poultry

1 Bratislav Pesić Ph.D., Professor, The High School of Agricultural-nutritional by Professional Studies, Ćirila and Metodija Street no. 1, 18000 Prokuplje, Serbia, Phone:+381 27324311 , E-mail: batta.pesic@gmail.com

2 Nikola Stolić Ph.D., Professor, The High School of Agricultural-nutritional by Professional Studies, Cirila and Metodija Street no. 1, 18000 Prokuplje, Serbia, Phone: +381 27324311 , E-mail: nikola.stolic@gmail.com

3 Božidar Milošević Ph.D., Professor, University in Pristina, Agricultural faculty in Lesku, 43500 Lešak, Kosovo, Phone:+381 2888 261, E-mail: bozidar.milosevic@pr.ac.rs

4 Zvonko Spasić Ph.D., Professor, University in Pristina, Agricultural faculty in Lesku, 43500 Lesak, Kosovo, Phone: +381 2888 261, E-mail: spasic.zvonko@pr.ac.rs

EP 2016 (63) 1 (61-70) 
production and the creation of appropriate reproce line with highly specialized production is conditioned by transition to the industrial mode of production. In recent years in the world and in our country, more and more often are used different methods that by chickens artificially interrupt the process of egg production, and after a certain period, shorter or longer, continuing the cycle of production.

This process in poultry is known as molting. Molting process is regulated by Thyroid gland hormones in which there is rest and regeneration of the reproductive organs, increasing the reserves of nutrients in the body of chickens, as well as to the replacement of feathers.

In the literature, numerous articles can be found on the topic analysis of artificial molting of heavy line hen hybrids. A large number of works relate precisely to the system of intensive breeding, due to the fact that the development of poultry production, in recent decades, moving towards its intensification. There are various methods for artificial hens in order to start a new production cycle. All of these methods can be divided into three groups (Hussein, 1996) method with limited food and water, the method of mineral-induced molting and molting which is caused by application of hormones. The most commonly applied method in practice is with limited food and water. The reason for its implementation is its simplicity and practicality. The effect of this method molting is reflected in a very fast reduction in the number of eggs up to 50\% after 10 days of treatment (Martin et al., 1973; Khoshoei, Khajali, 2006; Yousaf, 2002), or to a complete reduction of the number of eggs and interruption capacity for a period of 14 days (Gilbert, Blair, 1975; Odunsi et al., 2002). It is also clear that in the implementation of this molting method there was a drastic reduction of body weight, reduction of concentration reproductive hormones in blood plasma and increase the concentration of thyroid hormones (Verheyen et al., 1983a).

Method molting by restriction of food and water, corrected the light regime, gives different results in terms of termination of egg production and speed the return of molting chickens in capacity. It is generally acceptable that hens are starved for 10 days, lay their first egg after 5 weeks, while 50\% capacity back after 8 weeks from the start molting. (Hussein, 1996; Yousaf, 2002; Tops, et al., 2006). Involution of the ovaries and accelerated, but quite sufficient, regeneration causes reproductive organs quickly restore the load capacity of molting chickens and a larger mass of newly formed eggs (Donalson et al., 2005; Yousaf, Ahmad, 2006).

The resulting eggs in the production after molting used for incubation, showed significantly better results in terms of weight of the hatched chickens than eggs from continuous process of production (Oguike et al., 2004; Thomas et al., 2012). The aim of this study was to test the economic feasibility of molting hens-broiler parents, in one exploitation period. 


\section{Materials and methods}

The research was included throat heavy line COBB 500 hybrid, which were placed in one part of the building (a total of 3 identical parts) poultry farms in Gornje Crnatovo, near Nis. In a common technology on the farm parents approached settling manufacturing facility, or the beginning of exploitation. Based on the standard criteria of the animals in the facility were arranged and treated as a single group. The animals in the house were exposed to the same microclimate conditions, with identical positions relative to the light, ventilation, water, food and fertilization system. After completion of the operation in the normal cycle in the house is delivered required number of laying hens in order to compensate for the same, because of regular death in the production process, while males replaced by young roosters. It should be noted that in the first process of molting, parents consumed complete feed mixtures for nutritionwith $16.5 \%$ crude protein in the first ten days of fasting (except for roosters because they later settled), and in order to raise the body weight to the optimum.

Table 1. Number of parents in exploitation.

\begin{tabular}{|c|l|l|l|l|l|l|l|}
\hline \multicolumn{2}{|l|}{ Regular cycle } \\
\hline Age in the weeks & $\begin{array}{l}\text { Number of } \\
\text { heads }\end{array}$ & Male & Female & $\begin{array}{l}\text { Number } \\
\text { of heads }\end{array}$ & $\begin{array}{l}\text { A g e irst molting } \\
\text { in the } \\
\text { weeks }\end{array}$ & Male & Female \\
\hline 18 & 1,380 & 120 & 1,260 & 58 & 1,380 & 120 & 1,260 \\
\hline
\end{tabular}

Source: Authors' calculation based on a doctoral dissertation.

In order to perform the production control, the following parameters: the number of eggs laid, number of incubated eggs, egg mass laid down, the quantity of food consumed, the number of dead chickens were studied by the barn list. If it was possible, test the hypothesis of the differences between the average large independent samples according to Latinovic (1996) was performed. The resulting production indicators were used to determine the economic and financial analysis performance molting.

\section{Results and Discussion}

Table 2 shows, in parallel, the production results of the examined parental pairs on production cycles. Analyzing the total period of observation and monitoring the production results of parent couples of 462 days, it can be seen that broiler breeders showed a higher level of production in regular production cycle, despite the greater consumption of food that were recorded with parents in a regular cycle, a number of culled eggs and a smaller number of incubated eggs. 
Table 2. The values production indicators of female parents.

\begin{tabular}{|c|c|c|c|c|c|c|}
\hline $\begin{array}{c}\text { Cycle of } \\
\text { production }\end{array}$ & $\begin{array}{c}\text { Day of } \\
\text { exploitation }\end{array}$ & $\begin{array}{c}\text { The total } \\
\text { number of } \\
\text { eggs }\end{array}$ & $\begin{array}{c}\text { Average } \\
\text { capacity } \\
\text { (in \%) }\end{array}$ & $\begin{array}{c}\text { Consuming } \\
\text { the food per } \\
\text { day(in g) }\end{array}$ & $\begin{array}{c}\text { Consuming } \\
\text { the food } \\
\text { per egg (in } \\
\text { g) }\end{array}$ & $\begin{array}{c}\text { Mortality } \\
\text { (in \%) }\end{array}$ \\
\hline Regular & 280 & 273,207 & 77.44 & 152 & 206 & 6.81 \\
\hline I molting & 182 & 127,636 & 55.66 & 139 & 249 & 7.43 \\
\hline
\end{tabular}

Source: Authors' calculation based on a doctoral dissertation.

A larger amount of eaten food is caused by fact that parents during the regular production cycles have the highest daily and both the maintenance needs, especially in the initial period when a lot of energy consumed and used for promotion of body weight, while at the same time, and percentage increase in capacity. It is also evident that the highest recorded maximum capacity was during the regular production cycle, although it is lower than the amounts Yousaf et al. (2007) studying the consumption of food produced per egg can be observed that the chickens in the process of molting and consumed $43 \mathrm{~g}(20.9 \%)$ more food in relation to the chickens were fed during the regular operating cycle.

One of the most important production parameters monitored during exploitation period, primarily from an economic point of view, certainly the distribution or weight of eggs on which it is exercised and the corresponding number of eggs for incubation and the number of which directly affects the number of the hatched chickens through which prices are achieving an economic effect of production. Table 3 shows the number of eggs per distribution classes during exploitation period as a percentage (\%).

Table 3. Distribution of eggs per classes during exploitation (in \%).

\begin{tabular}{|c|c|c|c|}
\hline $\begin{array}{c}\text { Cycle } \\
\text { Classes }\end{array}$ & $\begin{array}{c}\text { Regular } \\
(\boldsymbol{X})\end{array}$ & $\begin{array}{c}\text { I molting } \\
(\boldsymbol{I})\end{array}$ & $\begin{array}{c}\text { Index } \\
\mathbf{I}(\boldsymbol{Y} / \boldsymbol{X})\end{array}$ \\
\hline $\mathrm{SU}+$ & 2.1 & 0.3 & 14.3 \\
\hline $\mathrm{SU}$ & 6.8 & 2.0 & 29.4 \\
\hline $\mathrm{S}$ & 24.2 & 37.5 & 155.0 \\
\hline $\mathrm{A}$ & 30.2 & 49.5 & 163.9 \\
\hline $\mathrm{B}$ & 17.6 & 5.5 & 31.3 \\
\hline $\mathrm{C}$ & 8.5 & 1.0 & 11.8 \\
\hline $\mathrm{D}$ & 5.2 & 0.1 & 1.9 \\
\hline E & 2.5 & 0.1 & 4.0 \\
\hline Dirty & 2.0 & 1.5 & 75.0 \\
\hline Cracked & 0.9 & 2.5 & 277.8 \\
\hline
\end{tabular}

Source: Authors' calculation based on a doctoral dissertation. 
The differences between $\mathrm{a}$ and $\mathrm{b}$ are significant at the level of $\mathrm{P}<0.05$, and between $\mathrm{a}$ and $\mathrm{c}$ at the level of $\mathrm{P}<0.01$. The analysis of the data obtained during the processing distribution eggs per class can be noticed that in the normal course of the production cycle obviously present a greater number of eggs so called outside class of eggs or eggs that are rejected due to their weight are not provided and conditionally usable for investment in the incubator (28\%). Naturally, this is driven by a large number of eggs produced whose weight exceeds $70 \mathrm{~g}$ each, $(\mathrm{SU}+\mathrm{SU})$ or with a mass of eggs and 50 grams less (C, D, E, soiled and cracked). This trend of egg mass was not registered in molting chickens during the first cycle of molting, because in this period of exploitation also notes the largest concentration of produced eggs around the middle classes $\mathrm{S}, \mathrm{A}$, $\mathrm{B}$, as well as in regular production cycle, although there is an evident difference in the distribution of eggs are removed as scrap eggs (7.6\%). These differences in the mass of eggs and have statistical significance, as shown in the table.

Showing an increase of egg mass during the first cycle of molting from the regular production cycle expressed in index points clearly indicates the trend of their increase and shift their weight to heavier classes. The same results were obtained in the research conducted by Gordon et al., 2009. By organizing data obtained from regular production cycle and the first molting process there was noticed very significant differences in the parameters that are logically impose such a conclusion. By comparing the number of eggs produced per cycle shows that in the normal production cycle production $(22 \%)$ more eggs. This is a clear indication to the advantage of exploitation of young flock number of fertilized eggs observed percentage points to the conclusion that it was a good choice of roosters in regular production process and in the process of molting. A larger number of culled eggs that appeared in the first production process points to the need to improve environmental conditions, but also to the advantage molting chickens. Detailed view of the production parameters are given in Table 4.

Table 4. The production parameters (in pieces, \%).

\begin{tabular}{|c|c|c|}
\hline $\begin{array}{c}\text { Cycle } \\
\text { Parameters }\end{array}$ & Regular & I molting \\
\hline The number of produced eggs & 273,207 & 127,636 \\
\hline$\%$ & 77.4 & 55.6 \\
\hline Number of fertilized eggs & 254,410 & 116,404 \\
\hline$\%$ & 93.3 & 91.2 \\
\hline Number of incubated eggs & 196,708 & 117,936 \\
\hline$\%$ & 72.0 & 92.4 \\
\hline Number of culled eggs & 71,234 & 9,700 \\
\hline$\%$ & 28.0 & 7.6 \\
\hline Number of the hatched eggs & 157,563 & 97,061 \\
\hline$\%$ & 80.1 & 82.3 \\
\hline
\end{tabular}

Source: Authors' calculation based on a doctoral dissertation. 
Further analysis of production results were partial or direct costs in different production cycles. Fixed costs (such as wages, amortization, utilities, etc.), were not observed and included in the calculations due to being completely equal impact in all production cycles. Winning results of cost analysis we used for comparison with the analysis of the data obtained income from the production value of day-old chicks, and thus occurred results that leads us to a conclusion during evaluating the profitability of production. The results of our analysis of the data we used to calculate the boundaries of economy which shows the situation when the cost of the same production value as well as costeffectiveness and profitability of molting hens for production purposes. Analyzing the economic parameters of broilers production we notes that the largest input costs in the normal production cycle $(290 \%$ more than in the first molt). This is understandable given the fact that the highest price, in addition to food consumption, supply flocks to start production. That kind of costs with molting do not have, because the hens that are used in the production process and further use to resume production. Comparing revenues during the regular production cycle with the first or second molt, it is noticed a clear difference between those processes.

Table 5. Financial and economic indicators of production broiler breeders in cycles.

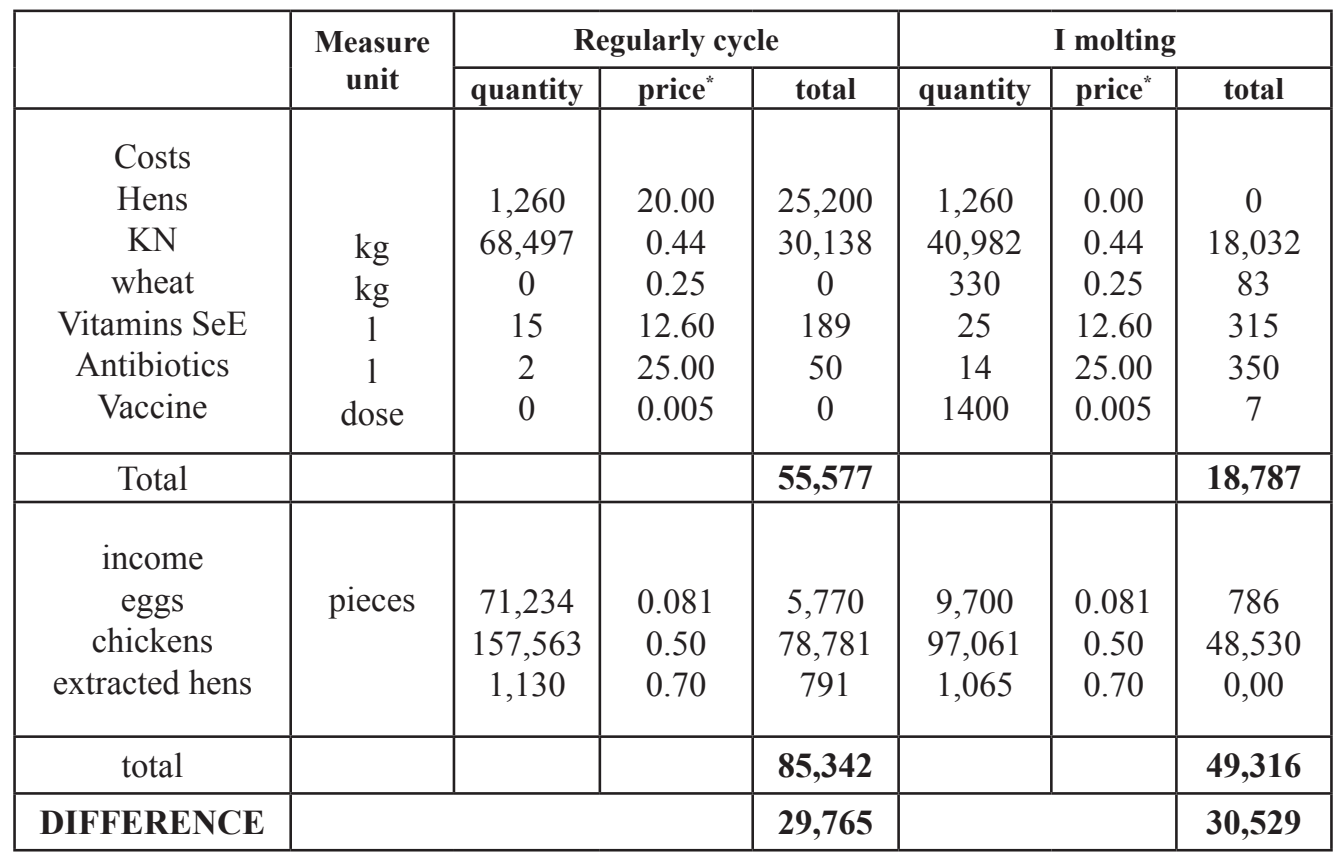

* Price in Euros taken from www.stips.minpolj.gov.rs on the day of 11.09.2012, $1 €=116.30$ din Bulletin ZS936, 11.9.2012.

Source: Authors' calculation based on a doctoral dissertation.

It is logical to expect the best results in the normal production process, because young chicks have the largest capacity in that period. However, in practice very common 
reasons why such rules and logic are not what is expected. These are exactly the reasons why, in our case showed that " profit "' is greater during the first molting in relation to the regular production process, or another molting. The higher profit was caused by lower input costs and a larger number of breeding conditional eggs for incubation (Spasic et al., 2011).

In detailed analysis of the income realized in the normal production cycle and the comparison with the revenue generated in the first molting recognize the cost-effectiveness of the program of molting and repeated exploitation of female broiler breeders. Actual revenue was $2.5 \%$ higher in the first molting from the regular cycle of production. Realizing the fact that apart from regular production cycle from the production process after the first molting, and that periods exploitation parents are not the same for these two periods, we started calculating revenue per production day, or revenue generated per hen housed during the entire production cycle, as shown in Table 6.

It may be noted that the average of net in compere hen during molting cycle after the regular cycle of production colored by $2.54 \%$ compared to the same indicators in the normal production cycle.

Table 6. Standardized net income of parent couples.

\begin{tabular}{|c|c|c|c|c|}
\hline $\begin{array}{c}\text { Production } \\
\text { cycle }\end{array}$ & $\begin{array}{c}\text { Exploitation } \\
\text { day }\end{array}$ & $\begin{array}{c}\text { The } \\
\text { average } \\
\text { number } \\
\text { hens per } \\
\text { day }\end{array}$ & $\begin{array}{c}\text { The average } \\
\text { revenue } \\
\text { per day of } \\
\text { production } \\
\text { (u } \boldsymbol{€})\end{array}$ & $\begin{array}{c}\text { The average } \\
\text { revenue per } \\
\text { housed hen(in } \\
€)\end{array}$ \\
\hline Regular & 280 & 1,195 & 106 & 23.62 \\
\hline I molting & 182 & 1,162 & 167 & 24.22 \\
\hline
\end{tabular}

Source: Authors' calculation based on a doctoral dissertation.

\section{Conclusion}

Based on the analysis of production results arising out of the research is the production of heavy line parental pairs in different production cycles, before and after molting, and in conducted economic and financial analysis, it can be concluded that:

-The total number of eggs produced during the normal operating cycle is significantly higher in comparison to the production during the cycle after the first molting, observed a percentage of capacity by $21.8 \%$.

-Hens after molting were producing eggs that did not meet quality standards and incubating for about $20.4 \%$ less than in chickens in the normal production cycle.

- Economic indicators of broilers production after the first molting demonstrate justification of these biological and technological operations, given that net income per housed per housed hens exceeds the same income in the normal production cycle. 
- Lack of forced-molting process of production is clearly observed and measured due to considerably lower production volume and therefore this type of production can be organized in the event of market disturbances, lack of new parent flock in semiintensive cultivation conditions of the parents, in order to maintain production with significantly reduced economic effect.

\section{Literature}

1. Donalson, L.M., Kim, W.K., Woodward C.L., Herrera, P., Kubena L.F., Nisbet, D.J., Ricke S.C. (2005): Utilizing different ratios of alfalfa and layer ration for molt induction and performance in commercial laying hens, Poult. Sci. UK, Vol. 84, No. 3, pp. 362-369.

2. Gordon, R., Bryant, M.M., Roland, D.A. (2009): Performance and profitability of second-cycle laying hens as influenced by body weight reduction during molt. Journal of Applied Poultry Research. Applied Poultry Science Inc, United States, Vol. 18, No. 2, pp. 223-231.

3. Gilbert, A.B., Blair, R. (1975): A comparison of the effects of two low-calcium diets on egg production in the domestic fowl. British Poultry Science, Taylor \& Francis Ltd, Abingdon, Oxfordshire, United Kingdom, vol 16, No. 6, pp. 547-552.

4. Hussein, A. S. (1996): Induced molting procedures in laying fowl. World's Poultry Science Journal, CABI Publishing, Wallingford, Oxfordshire, United Kingdom, Vol. 52, No. 02, pp. 175-187.

5. Khoshoei, E. A., Khajali, F. (2006): Alternative induced molting methods for continuous feed withdrawal and their influence on postmolt performance of laying hens. International Journal of Poultry Science, Asian Network for Scientific Information, Vol. 5, No. 1, pp. 47-50.

6. Latinović, D. (1996): Populaciona genetika - praktikum. Univerzitet u Beogradu, Poljoprivredni fakultet Zemun Beograd.

7. Martin, G. A., Morris, T. B., Gehle, M. H., Harwood, D. G. (1973): Forcemolting by limiting calcium intake. Poultry Science, Vol. 52, No. 5, pp. 2058-2058.

8. Odunsi, A.A., Farino, G.O., Togun, V.A. (2002): Diet manipulation and postmolting responses in caged laying hens, Nigerian J. Anim. Prod. Vol. 29, No. 1, pp. 11-15.

9. Oguike, M. A., Igboeli, G., Ibe, S.N., Uzoukwu, M. (2004): Effect of day length and feed/water regime on induction of feather molt and subsequent laying performance in the domestic fowl, Int'1. Journal of Poult. Sci. UK. Vol. 3, No. 8, pp. 507-512.

10. Spasić, Z., Milošević, B., Pešić, B., Ćirić, S., Samardžić, S., Omerović, I., Stolić, N. (2011): Ekonomska opravdanost dvostrukog mitarenja lakih linijskih hibrida u uslovima ekonomske krize. Economics of Agriculture, Vol. 57, SI 1, Book 2, pp. 154161 (UDC 338.43:63 YU ISSN 0352-3462 UDC: 636.5: 339.976).

11. Thomas, T, Gilbert, J, Meyer, F. (2012): Metagenomics - A guide from sampling to data analysis. Microb Inform Exp. Vol. 2, No. 1, p. 1.

12. Tops, M., van Peer, J. M., Wester, A. E., Wijers, A. A., Korf, J. (2006): Statedependent regulation of cortical activity by cortisol: an EEG study, Neuroscience 
Letters Vol. 404, No. 1, pp. 39-43

13. Yousaf, M., Ahmad, N., Khan, S., Ahmed, T. (2007): Effect of non-feed withdrawal induced molting techniques on feather molt scoring and egg production of caged hens. Sarhad Journal of Agriculture, Faisalabad, Pakistan, Vol. 24, No. 2, pp. 331-338.

14. Yousaf, M., Ahmad, N. (2006): Influence of different copper and aluminum levels on organ weights, feather renewal and production performance of molted layers. Pakistan. Journal. Arid Agric. Vol. 9, No. 1, pp. 35-39.

15. Yousaf, M. (2002): The impact of mineral supplementation and feed deprivation on plumage renewal of commercial layers kept on litter floor system, 33rd All Pak. Sci. Conf. 25th to 28th December, 2002 at Univ. Agric., Faisalabad. pp.16. Pakistan

16. Yousaf, M. (2004): Influence of different copper and aluminum levels on feather renewal and production characteristics of the layers in the second production cycle, Research project report submitted to Pakistan Science Foundation, Islamabad, Pakistan.

17. Verheyen, G., Decuypere, E., Kuhn, E.R., Fontaine, G., Groote, G.DE. (1983a): Moult induction in the hen. Effect of different methods on some performance traits and on thyroid hormone, prolactin. $\mathrm{Ca}, \mathrm{P}, \mathrm{Na}$, and protein concentrations in blood serum. Reeub de I, Journal of Agriculture. Pakistan 36:1535-1559 


\title{
MITARENJE BROJLERSKIH RODITELJA USLOV ZA EKONOMSKU OPRVADANOST NASTAVKA PROIZVODNJE
}

\author{
Bratislav Pešic ${ }^{5}$, Nikola Stolić, Božidar Milosević7, Zvonko Spasić ${ }^{8}$
}

\begin{abstract}
Rezime
Metod veštačkog prekidanja procesa proizvodnje kod kokošaka, brojlerskih roditelja, danas poznatiji pod nazivom mitarenje, veoma se često koristi poslednjih godina kao jedan od mogićih opravdanih koraka prilikom donošenja odluke o isplatljivosti nastavka eksploatacije brojlerskih roditelja nakon redovnog procesa proizvodnje.Cilj ovih istraživanja bio je ispitivanje ekonomske isplativosti mitarenih kokoši-brojlerskih roditelja, a u toku jednog eksplatacionog perioda.Istraživanjem su bila obuhvaćena grla teškog linijskih hibrida COBB 500. Životinje u objektu bile su izložene istim mikroklimatskim uslovima, sa identičnim pozicijama u odnosu na svetlost, ventilaciju, vodu, hranu i sistem za izđubrivanje. Analizom utroška hrane po proizvedenom jajetu uočava se da roditelji nosilje u toku procesa mitarenja konzumiraju više hrane za 43\% u odnosu na nosilje hranjene u redovnom ciklusu proizvodnje. Ostvareni prihod je za 2,54\% veći nakon obračuna kod mitarenih kokošaka u odnosu na redovan ciklus proizvodnje.Ekonomski pokazatelji proizvodnje jaja nakon mitarenja pokazuju opravdanost primene ove biološko-tehnološke operacije, obzirom da neto prihod po useljenoj kokoški isti prihod u redovnom procesu proizvodnje.
\end{abstract}

Ključne reči: mitarenje, brojlerski roditelji, nosivost, pilići, ekonomičnost.

5 Profesor, dr Bratislav Pesić Visoka poljoprivredno-prehrambena škola, Ulica Ćirila i Metodija br. 1, 18000 Prokuplje, Srbija, Telefon: +381 27324 311, E-mail: batta.pesic@gmail.com

6 Profesor, dr Nikola Stolić, Visoka poljoprivredno-prehrambena škola, Ulica Ćirila i Metodija br. 1, 18000 Prokuplje, Srbija, Telefon: +381 27324 311, E-mail: nikola.stolic@gmail.com

7 Profesor, dr Božidar Milošević, Univerzitet u Prištini, Poljoprivredni fakultet, 43500 Lešak, Kosovo, Telefon:+381 2888 261, E-mail: bozidar.milosevic@pr.ac.rs

8 Profesor, dr Zvonko Spasić Univerzitet u Prištini, Poljoprivredni fakultet, 43500 Lesak, Kosovo, Telefon: +381 2888 261, E-mail: spasic.zvonko@pr.ac.rs 